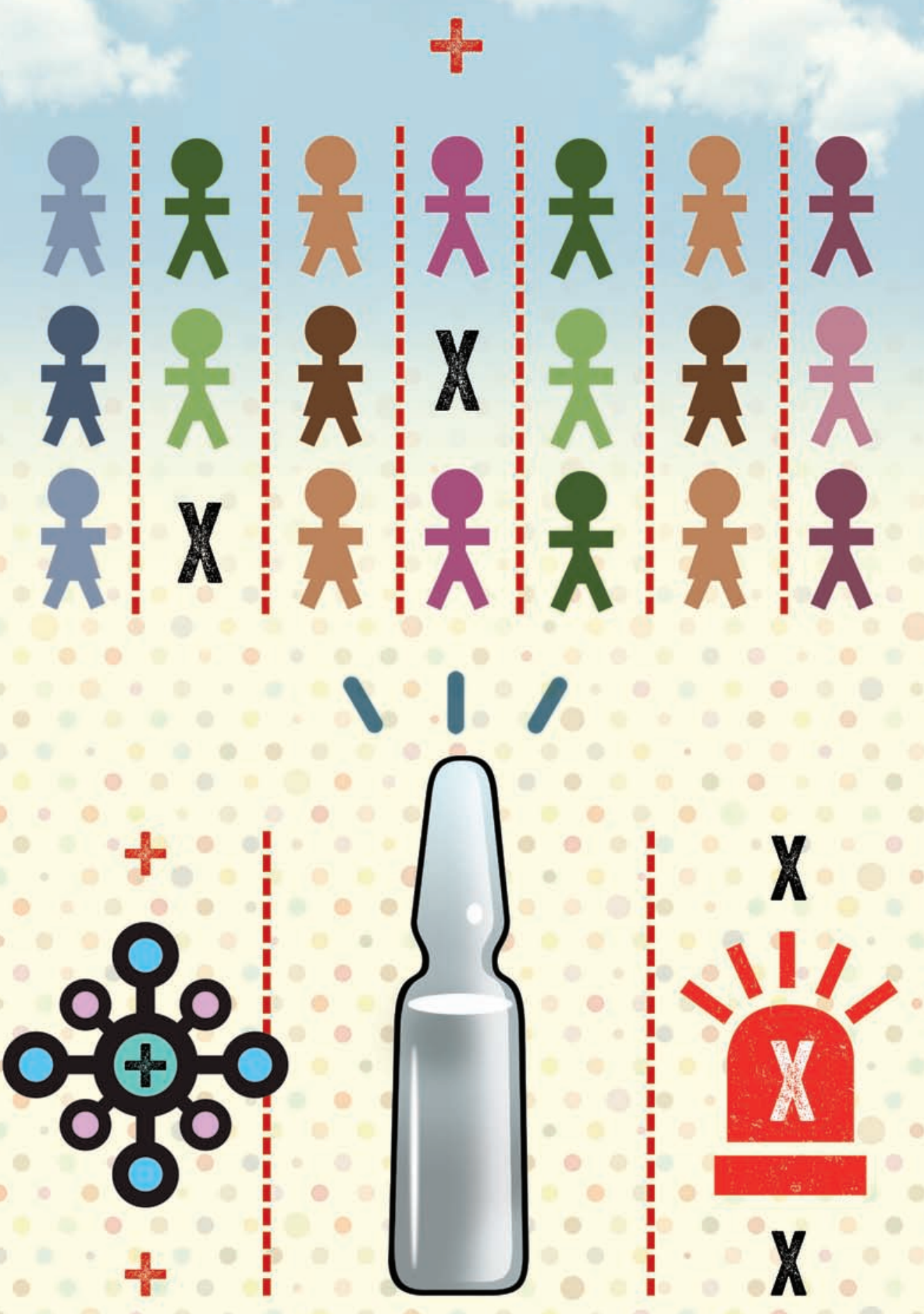




\title{
Rethinking diffusion of vaccines: giving healthcare a better shot
}

\author{
Repensando a Difusão de Vacinas: a \\ Importância da Contabilidade Democrática \\ para a Difusão de Tecnologias de Saúde \\ Pública
}

* Paulo Savaget

\begin{abstract}
Vaccination is an area of rapid scientific and technological advance and is among the most successful public health interventions ever. However, for its potential to be met, innovation systems should not only make vaccines available: it is also essential that delivery systems suit social desires and local peculiarities. This work presents 2 cases of failures in diffusing vaccines, as social, cultural and political aspects were not well addressed throughout the campaigns. Lessons taken from these cases suggest that instead of focusing merely on increasing immunity, policies should integrate interdisciplinary bodies of knowledge and promote social engagement through bottom-up processes. These approaches are not only keener on improving acceptability and efficacy in delivering existing technologies, but also to create (and adapt) novelties based on local capabilities.
\end{abstract}

Keywords: Innovation Systems; Diffusion; Vaccines.

\begin{abstract}
Resumo
A vacinação é uma área de rápidos avanços científicos e tecnológicos e as campanhas de vacinação estão entre as intervenções mais bem sucedidas em políticas de saúde pública. No entanto, o potencial de difusão de qualquer tecnologia vai muito além de disponibilizar o seu acesso: é essencial que a difusão seja compatível com os desejos sociais e peculiaridades locais. Esse artigo apresenta 2 casos de fracasso na difusão de vacinas, em virtude da inabilidade das campanhas de vacinação de endereçar aspectos sociais, culturais e políticos. Lições extraídas desses casos sugerem que ao invés de focar exclusivamente em aumentar a imunidade, as políticas deveriam integrar conhecimentos interdisciplinares e promover o engajamento social através de processos bottom-up. Essas abordagens não são apenas mais capazes de aumentar a aceitabilidade e eficácia na difusão das tecnologias existentes, mas também de estimular a geração (e adaptação) de tecnologias baseadas nas capacitações locais.
\end{abstract}

Palavras-Chave: Sistemas de Inovação; Difusão; Vacinas.

\footnotetext{
* Mestre em Science and Technology Policy pelo SPRU - University of Sussex; Mestre em Políticas Públicas, Estratégias e Desenvolvimento pela Universidade Federal do Rio de Janeiro (PPED/UFRJ). 


\section{Introduction}

Innovation is a dynamic process, influenced by different sets of agents and institutions. This term is used to describe much more than an outcome, including the whole process instead, from creation to diffusion (Schumpeter, 1982). Absorption and imitation of novelties created elsewhere are also important forms of diffusion, involving underlying progresses on technological capabilities and learning (Teece, 1988). Diffusion of innovation- as well as its generation - is embedded by uncertainty and complexity, and should not be seen as straightforward processes. A systemic approach of innovation provides a better understanding about how technical change occurs, explaining why some characteristics are continuously reinforced in order to keep coherence (Dosi, Nelson \& Winter, 1999) or as results from lock-ins (Arthur, 1988). All these characteristics combined attribute continuity, cumulativeness, non-linearity and path-dependency to innovation processes.

The propensity of nations, sectors or regions to create and diffuse innovation is thus influenced by a diverse set of institutional features, reflecting, for instance, their cultural, political, social, environmental and economic dimensions (Lundvall, 1992). It is consequently difficult to assert policy recommendations for progress as they vary according to continuously co-evolving features. Yet, as innovation systems are essentially path-dependent, lessons from history help to identify constraints and opportunities for future progress.

Along these lines, this work investigates failures in diffusing vaccines. Thanks to an unprecedented global effort, there are now billions of dollars available for health spending. Immunization campaigns, for example, are increasingly covering all countries in the world (Garett, 2007). However, much more than delivering medicines is in fact required. Technological diffusion is a rather chaotic process, embedded by uncertainty, and shaped by cultural, political and social aspects. Consequently, delivery systems should suit social desires and local peculiarities. Most initiatives have focused in straightforwardly diffusing "silver bullet"technologies, based on a simplistic understanding of innovation systems. Leaving these complexities aside while diffusing vaccines can, nevertheless, be extremely counterproductive.

This work will present 2 cases of failures in diffusing vaccines. These cases correspond to: measles, mumps and rubella (MMR) in the United Kingdom (UK) and oral polio in Nigeria. They were chosen according to their potential to unravel relevant evidences in questioning the existence of single, universal technologies that can be equally replicated in every context.

The remainder of this paper is structured as follows. The first Section sets the research design, which includes the research question, the main hypothesis motivating this work, as well as a description of the case study methodology. The second section presents the theoretical background. The third Section presents the two case studies. The last section explores the empirical evidences; links them to 
the theoretical background; and finally concludes the paper by describing its limitations and suggesting possibilities for future research.

\section{Research Design}

\section{Research Question and Hypothesis}

This work aims at investigating the following research question: Are nontechnological aspects (such as social behaviour, culture, geography, politics and prevailing institutions) critical to effectively diffuse vaccines?

The main hypothesis behind this question is that major health initiatives are not properly tackling diseases, as they are narrowly focused in discovering and making "silver bullets", such as vaccines, available. However, these policies neglect that much more is in fact needed than just making vaccines available.

\section{Method}

The case study method consists on the intensive investigation - both in depth and width - of the object of analysis, in order to provide the most complete understanding possible (Yin, 2009). This method is the most appropriate to address the inquiries on the efficacy of the diffusion of vaccines in processes that neglected non-technological aspects.

This research design is a multiple-case, inductive study. Multiple case studies are particularly reliable to answer questions that remain unanswered. This method is capable both of generating new concepts - through the unravelling of empirical events that were not observed by previous theories - as well as through the investigation of hypothesis emerging from conceptual insights. Theories emerging from (or tested by) multiple cases are typically more generalizable than the ones derived from single-case studies, making them more likely to be validated through other research methods (Eisenhardt \& Graebner, 2007). This work will explore whether diffusion of medical silver bullets are effective, so to test the hypothesis that current global health initiatives are not following a good path.

In order to do that, information on the subject was collected from various secondary sources. Instead of dealing with a handful of cases, only two were chosen in order to allow scope for descriptions in wide and depth. The cases chosen are namely the vaccine controversy in the United Kingdom and oral polio in Nigeria. Both cases are about the diffusion of a highly sensitive medical technology: vaccines for child immunization. As a consequence, these choices are justified by their relevance, as they are particularly capable of contributing with clear and distinct experiences about the topic. Triangulation of information extracted from the database was an important tool to increase accuracy and as a means of avoiding misinformation. Furthermore, authors with different viewpoints on same cases were integrated to the analysis in order to improve the reliability of the study. 


\section{Theoretical Background}

\section{Shedding light on innovation}

An essential aspect of economic development that has been relegated to the periphery of mainstream frameworks consists on comprehending the innovation dynamics. While deepening into descriptive ceteris paribus relationships between labour and income, neoclassical theories have conceived innovations merely as exogenous events. Innovation was understood as spontaneous and sporadic discoveries, resulting from embodied creativity and geniality (Solow, 1956). Policies according to these frameworks were, therefore, based on recommendations of laissezfaire and laissez-innover (Freeman \& Soete, 2000), as interferences in the market would cause negative effects in a system that naturally tends to an optimum equilibrium. Moreover, innovation could not be internalized, managed, neither stimulated. In other words, equilibrium would be achieved through the invisible hands of the market, and innovation could not be handled, while treated as exogenous events.

In Schumpeter's theory (1984:113) innovation - and its creative destruction occupied, instead, a prominent place, interpreted as "what capitalism consists in and what every capitalist concern has got to live in". Innovation has been further described as a dynamic process, with the capacity of influencing and be influenced by a different set of agents, especially by firms. Firms are the main agents of this dynamic, as commercialization is an essential feature of innovations (Coriat \& Weinstein, 2002).

The comprehension of the central role played by firms can be understood while describing the differences between invention and innovation: terms that are commonly treated as synonyms. Invention is an idea, a draft or a model to a new product, a service, a design or a process that can be patented, even if not necessarily exclusively technological. An innovation, on the other hand, is obtained with the first commercial transaction of a novelty, but it is generally used to describe the whole process, after creation, through implementation to diffusion (Schumpeter, 1982). Furthermore, absorption and imitation of prior novelty created elsewhere are both important forms of diffusion - as long as it comes with an underlying progress on the organizational learning and technological capabilities (Teece, 1988).

It has been observed by the literature that innovation should not be seen as a singular event, but a rather systematic process (Freeman \& Soete, 2000), that goes beyond creativity, and is necessarily driven by firms. In addition, innovation dynamics are highly uncertain and complex (Tidd, 2001). Uncertainty derives from the fact that results of innovative processes cannot be anticipated, while complexity comes from the interrelationship between the dimensions involved in these processes: technical, social and economic (Kline \& Rosenberg, 1986).

Unlike mainstream economics, 'evolution' of firms, sectors and nations became theoretically more complex, path-dependent and impossible to foresight. Developing a general theory of innovation that abstracts from time and space would consequently 
undermine the utility of the concept both as an analytical and as a policy tool (Lundvall, 1992; Freeman \& Soete, 2000). There is, though, a possibility of understanding innovation processes anchored on theoretical background and on history.

\section{The Systemic Approach of Innovation}

The systemic approach considers the complexity, uncertainty and multidirectional features of innovation, which "creates kaleidoscopic succession of new possibilities and combinations" (Freeman, 1979:226). It analyses the interaction of science, technology, and the market, as well as the role of their interaction to drive technical change. Instead of examining simple blocks (or variables) and their causal relationships ${ }^{1}$ the focus has shifted to interacting systems. The theoretical tendency thus moved to comprehend the properties of these systems and their interactions with underlying institutional framings and macro-environmental contexts.

According to Malerba (2004), innovation systems can be characterized by the interaction of the three following dimensions:

I. Knowledge and technologies: While stressing the importance of learning process, creation and diffusion of knowledge and technology, and how dynamic technological capabilities (Teece, 1988) and routines (Nelson \& Winter, 1982) are built, innovation dynamics acquired a cumulative perspective, becoming essentially path-dependent. As tacit knowledge (Cowan, David \& Foray, 2000) is not easily transferred, differences between firms, sectors and nations can be justified in a globalized world.

II. Actors and networks: Non-market relationships between firms and other agents for instance, their suppliers, consumers, public bodies, universities and research institutes - have not only been used to describe innovative dynamics, but also to suggest an increasingly important behaviour for their future success (Chesbrough, 2006). While growing investments in $R \& D$ and defensive organizational behaviour were important characteristics after the World Wars, many contemporary authors have signalized a shift to a more collaborative framework. This would improve how they deal with the complexities and uncertainties, enabling them to connect tangible and intangible assets of different agents to drive innovations. That is the case, for instance, of the triple helix (Leydesdorff, 2000), the open innovation (Chesbrough, 2006), the user innovation (Von Hippel, 2001), and the stakeholder engagement (Freeman \& Reed, 1984). Indeed, new forms of organizations, such as spin-offs and joint ventures have emerged in order to cope with these windows of opportunities.

III. Institutions: Aggregating inter-institutional features also bring important dimensions to understand innovation systems (Castro, 2004). Nelson and Sampat (2001), for example, presented how institutions are important for evolutionary 
economics, in a framework in which institutions are dynamically interrelated with physical and social technologies. Understanding how institutions constrain or enable (Hodgson, 2005) innovative processes is essential to better understand the evolution of firms and nations. Freeman and Perez (1988) and Freeman and Louca (2001), both in macroeconomic perspectives, have suggested that the most economically successful countries had different sets of supporting institutions already in place when they were historically needed, and that these nations were capable of appropriating new institutions in order to stimulate their progress.

It is important to stress that all these characteristics of a systemic approach of innovation provide a better understanding about how technical change occurs in firms, sectors and nations, as well as to explain why some of their characteristics are continuously reinforced in order to keep coherence (Dosi, Nelson \& Winter, 1999) or as results from lock-ins (Arthur, 1988).

Finally, there are some consensuses about the characterisation of innovation processes by most contemporary authors of the evolutionary theory of economics. Innovation can be characterized as a continuous, cumulative, systemic, non-linear, path-dependent and generally chaotic process (Van De Ven, 1986; Tidd, 2001). It consists not only in commercializing new products, services or technologies, neither only in generating new processes or business models. It also aggregates processes of market diffusion, as well as absorption and imitation of novelties created elsewhere. Thus, they can be classified in terms of impacts they generate - commonly categorized as radical (disruptive) or incremental (Freeman \& Perez, 1988; Christensen, 2000).

\section{Innovation and Learning Systems}

One of the most influential sets of writing in evolutionary economics refers to the theory on Innovation Systems, which could focus on different levels of analysis, such as the regional, national and sectorial (Cassiolato \& Lastres, 2005). This concept aggregates the patterns of behaviour of firms, the cooperation and competition among organizations, and the role of research entities, universities, civil society, the prevailing laws and public policies (Lundvall, 1992). All these features are dynamically interrelated and continuously coevolving. A systemic approach breaks up with linear comprehensions of economic behaviour, highlighting the central role of institutions and how their relationship with firms configure "not a congruent and smooth evolution, but rather a dynamic form of interplay, accompanied by more or less strong tensions" (Coriat \& Weinstein, 2002:21).

Focusing on national boundaries (the so-called National Innovation Systems) requires analysing "the network of institutions in the public and private sectors whose activities and interactions initiate, import, modify and diffuse new technologies" (Freeman, 1987:1), and which are "either located within or rooted inside the borders of a nation state" (Lundvall, 1992:2). The innovative character of nations and, consequently, 
their competitive positioning, is influenced by a diverse set of institutional features, reflecting their cultural, historical political, social and economic characteristics.

Certain institutions and national characteristics seem to be more prone to configure a solid National Innovation System, constituting a selective environment, which minimizes uncertainties and endogenizes technological progress (Albuquerque, 1997). Instead of becoming standardized with the contemporary globalization, these national features became even more important to shape international competitiveness (Lundvall, 1988; Porter, 1990).

The "National Innovation System" approach has indeed being extensively used to understand interconnections between technical change, growth and development, consequently configuring an important framework to analyse evolution in advanced economies. Viotti (2002) nevertheless suggests that this terminology is not appropriate to label development of countries below the technological frontier, as proprietary innovations play a secondary role in their process of technical change. These countries develop mostly through diffusion of foreign technologies and incremental innovations, especially focused on processes and on adapting technologies generated elsewhere to local realities. It constitutes mainly a learning process and, therefore, the terminology National Learning System might be better to describe technical change in latecomers.

The term 'learning' can be used for absorption of already existing techniques, as well as to improve the acquired ones. The opportunities and behaviour of national firms while generating incremental innovations can be classified as passive or active. The first is more associated to absorption that does not require an expressive underlying technological effort, such as licensing. The second, on the other hand, requires mastering the absorbed technologies, for instance through imitation or reverse engineering. Even though both might promote institutional change and increase technological capabilities of national firms, the second form of absorption is keener on fostering rapid and solid development (Viotti, 2002).

Finally, it is important to stress that strategies to stimulate passive learning tend to be more recurrent in backward countries. However, active learning is a necessary step towards reaching more radical pathways in future and, consequently, to generate proprietary innovations in the long run (Viotti, 2002). Fostering active learning should, consequently, be a priority of national policies of latecomers, requiring institutional change and incentives for industrial dynamism.

\section{What Undifferentiated Innovation Policies do not Recognize?}

After analysing the theoretical background from the previous sections, it is important to observe that an innovation policy, according to these theories, cannot be replicated among different countries, even if they are in similar patterns of development. In this case, characteristics from national institutions and firms would be neglected, and the systemic dynamics of innovation would be undermined. 
The non-linear and rather chaotic characteristics of innovation dynamics pose certain difficulties for postulating assertive normative policy indications for future progress. Possible recommendations for countries differ substantially among their patterns of development, most importantly due to the 'stock' of capabilities of national organizations, as well as to their own peculiarities - such as social, cultural, environmental and economic. It is possible, though, to design policies anchored on a deep comprehension of each national system, identifying its constraints, as well as promoting initiatives that have proven to be keener on succeeding.

Policies to foster innovation tend, nevertheless, to be advocated through technocratic discourses. Although most theorists in this arena emphasise differences in instruments and processes in the pursuit of progress, innovation discourses often assume undifferentiated and normative policy-recommendations. Indeed, discourses of technocratic policy-makers usually endorse utilitarianism and the idea of humans as rational choosers. They tend to present an unconditional support to science, technology and innovation, arguing that the results are necessarily serving the public good (Jasanoff, 2009). Still, the concern here is merely identifying best ways of stimulating science and technology, which will shape 'the future of human race': no scope is left to the other way around.

Consequently, these narratives obscure the essentially normative character of human intentionality upon the directions of progress. Choices are denied to the majority of the population while political decisions are justified as 'based on scientific evidences' or by 'expert-based assessments'. Deliberately evaluative choices tend, as a consequence, to be left aside (Stirling, 2007).

Dissent to technocratic narratives has been treated in the political arena as a'march of unreason' (Taverne, 2005), 'anti-technology anxieties' (CEC, 2005), or as 'members of the "flat earth society", opposed to modern economics, modern technology, modern science, modern life itself' (Malloch-Brown, 2001)². Conversely to these perspectives, studies have presented the plurality of dissent values, interests and expectations regarding contentious technological pathways - such as GM Crops (Millstone, 2007), Stem Cells (Acero \& Savaget, 2011) and Nuclear Power (Berkhout \& Mackerron, 2009) and how their faithful advocators have casted opponents as Luddites, science deniers, irrational, ignorant, misguided or eco-fundamentalists. Laypeople are commonly presented as scientifically uninformed, or even as illiterate. Hence, technocratic views argue that dissent should not be taken seriously for policy purposes, as the ultimate goal of technological progress is given and immutable, and the means to achieve this goal is best identified by expert-based assessments.

\section{Public Health and Diffusion of Vaccines}

While less than a decade ago the biggest problem was the lack of resources to fight diseases affecting the poor, nowadays, thanks to an unprecedented rise in public 
and private donations, more money has been shifted to tackle health challenges. The World Bank recognised that diseases in poor countries were themselves critical obstacles to development, formally announcing the change in 1993, in its annual report (Garrett, 2007). Since then, in what concerns an agenda for public health by intergovernmental organisations and private donors - such as Bill and Melinda Gates Foundation - the tendency is investing in drugs discovery and diffusing the novelties around the globe.

The motivation behind these investments can be many, such as moral duties, public diplomacy, and investment in self-protection - as microbes know no boarders (Garett, 2007). Most of health aid has been, though, allocated to find "silver bullets" for specific diseases: not necessarily the ones that cause more deaths. This notion of progress, in a global dimension, favours public health efforts to heal high-profile diseases that can be a threat to national security of developed regions (Elbe, 2005). This stove-piping tendency reflects particular interests and concerns of donors: not the receivers. In other words: "most funds come with strings attached and must be spent according to donors' priorities, politics, and values" (Garrett, 2007:21).

Accordingly, data from the OECD shows that approximately a quarter of all global health investments has been allocated to HIV, although this disease constitutes only $5 \%$ of the burden of low and middle income countries, measured by'disability adjusted life years lost' (DALYs). This is, for instance, less than deaths caused by respiratory infections and perinatal conditions. If the only motivation behind these investments is improving global health, these statistics suggest that investments have been allocated counterproductively. In fact, much of these investments in finding "silver bullets" against high-profile diseases would generate more benefits if shifted to bed nets to prevent Malaria and Yellow Fever, family planning, birth assistance to prevent infant deaths, and immunisation against pneumonia. Low-profile diseases would, probably, receive better care if children in developed countries died from pneumonia, or if middle class women in developed countries died in childbirth (England, 2007).

Besides the underfunding of several health hazards, especially the so-called neglected tropical diseases, these patterns of investments have other deleterious effects. While attempting to find and diffuse drugs for HIV, for example, policies tend to separate this disease from sexual and reproductive health, creating "parallel structures that constrain the development of health services" (England, 2007:344). Moreover, conceiving public health as something 'objective' cloaks comprehensive understandings of technological diffusion under positivistic and undifferentiated pro-innovation discourses. Effectiveness of technological diffusion goes beyond making medicines available. Studies on National Innovation/Learning Systems have shown that they also require a broad understanding of the local features, traditional knowledge, social behaviour, cultural aspects, and so forth.

Much more than making money available is thus required for global health. The starting point for most contemporary initiatives is developing "silver bullets", such as 
vaccines, to control or even eliminate the hazards. However, it takes more than drugs to deal with healthcare systems. Even when a disruptive vaccine is discovered, sometimes it fails in fighting a disease. While all cash tends to flood to R\&D or leak away due to bureaucracies throughout the operationalization of health policies, there is a lack of measures to stimulate other important features. It is notable, for instance, how scarce are efforts to foster social engagement; the lack of interdisciplinary approaches while dealing with health hazards; as well as the underfunding in low-income countries for human skills and infrastructure - such as hospitals, clinics, laboratories.

The success in diffusing technologies is also related to social understandings and desires concerning their own health. According to Garrett (2007:16), no existent provisions allow the "poor to say what they want, decide which projects serve their needs, or adopt local innovations". In an opposite direction, health professionals usually label dissent to disruptive medical technologies - such as vaccines -as scientifically uninformed or even ignorant (Blume, 2006).

These positivistic perspectives take scientific knowledge as universal truths and neglect all the aspects related to technological diffusion. While anti-vaccination movements are re-emerging, public health authorities are too focused in finding ways of 'informing ignorant people of the real truth'; instead of integrating lay knowledge into vaccination processes, understanding people's anxieties, and engaging the society in public health assessments (Leach \& Fairhead, 2007). Therefore, criticism to the current policies addressing health challenges goes beyond morality: these policies are also essentially counterproductive and lack analytical rigor.

\section{Learning from Past Experiences}

\section{Oral polio in Nigeria}

The Global Polio Eradication Initiative (GPEI) is led by the World Health Organization (WHO), Rotary International, UNICEF and the US Centre for Disease Control and Prevention (CDC) and is the largest public health initiative in the world. GPEl set a target to eradicate polio in 125 countries by 2005 and, through the alliance with institutions worldwide, it came to achieve high rates of immunizations. There are two varieties of polio vaccines: one of which (named Sabin) is given orally and is highly diffused in the world, due to its efficacy and to the easiness in handling its vaccination campaigns (Eigen, 1997). However, by 2003, polio remained endemic in seven countries, but mostly in Nigeria. According to a WHO report (2002), more than $40 \%$ of new cases of polio in the world in 2002 were in Nigeria, and this high incidence was attributed to an insufficient coverage of OPV (oral polio vaccination) programs. Polio was more concentrated than ever in predominantly Muslim states in northern Nigeria. These were among the few regions in the world to present a rise in incidence, registering a fourfold increase in cases by 2001 (WHO, 2002). 
These GPEI targets turned into a far reality in 2003 when Muslim political leaders in northern Nigeria - under the umbrella of the Supreme Council for Sharia in Nigeria (SCSN) - organized a standstill, as a response to a fear that vaccines were deliberately contaminated with HIV virus and anti-fertility drugs. The Polio Eradication Initiative in Nigeria was seen as a plan led by western governments to decrease the Muslim population in the world. This controversy resulted in a spread of polio within Nigerian boarders and to other western and central African countries, diminishing the possibilities of meeting GPEl eradication targets and jeopardizing their previous accomplishments (Yahya, 2007).

Historical and political features are essential to understand how the 'gunpowder trail was lit', propagating a profound distrust in polio vaccination programs. The struggle for power between three dominant ethnic groups has been a historical source of friction. The federal government, responsible for the campaigns in 2003 was not representative of the Muslim region in northern Nigeria. This region also happens to have the highest incidence of polio in the country, creating suspicions over the fact that Muslims were the main targets of vaccination programs (Renne, 2006). As stated by an interviewed Nigerian pharmacist: "This feeling has only intensified following events such as the September 11 attacks and the US invasion of Iraq and Afghanistan ${ }^{3 \prime}$, creating a perception that western countries were not fighting specific countries, but aiming at extinguishing Muslims (Yahya, 2007).

While cautioning parents about the dangers of vaccinating their children, political leaders boycotted the campaign, propagating fear against western-led initiatives. As stated by an inhabitant of a northern region: "We believe that modern-day Hitlers have deliberately adulterated the oral polio vaccines with anti-fertility drugs and contaminated it with certain viruses which are known to cause HIV and AIDS"."

Another reason for refusal was the fear caused by past incidents concerning alleged malpractices in a trial of the antibiotic Trovan ${ }^{\circledR}$ from Pfizer, that has been later withdrawn from the US market due to serious liver injuries as adverse effects. This drug was given for free for 100 children infected with meningitis in 1996 in a region located in the north of Nigeria. Instead of a philanthropic action, it was instead a clinical trial that allegedly did not fully informed patients of the risks, and to which the death of approximately 11 children is attributed (Achebe, 2004). This fact also contributed to increase resistance to Western medicines.

Furthermore, the SCSN also claimed the discovery of documents proving that the WHO and UNICEF have been involved in the development of anti-fertility vaccines administered together with tetanus prevention for more than 20 years. It is interesting to observe here how international health programs can lose its "cloak of neutrality, acquiring significant political and cultural meanings reflective of a global political climate" (Yahya, 2007:192).

Besides the political climate, labelling the polio vaccination refusal in Nigeria exclusively as a political controversy is not accurate. There are several reasons regarding 
social understandings of what health programs should be. A key aspect here is the disagreement with the "stupendous spending on polio by donor agencies, in spite of the presence of more destructive diseases ${ }^{\prime \prime}$. Non-compliers did not prioritize polio immunization. Malaria was a much bigger problem and for them spending resources on polio was at least doubtful. It did not make sense, for instance, why the polio vaccine was given for free while malaria medicines had to be paid for. As Renne (2006:1866) explained: "people were questioning a top-down government decision to promote a public health initiative that came from outside, an initiative in which they had no input".

Therefore, the vaccination program inspired a controversy with cultural, social and political dimensions: "beneath the great visions, power struggles and diverse motivations remain the perplexed communities of northern Nigeria who strongly desire a well-functioning and affordable health care system that takes care of malaria, pneumonia, typhoid and polio" (Yahya, 2007:204).

There is also a significant dissatisfaction with the quality of the primary health care and the focus on fighting a single disease strengthened non-compliance to the program. In fact, a research by Feilden Battersby Analysts (2005) suggested that the quantity of human and financial resources invested in fighting a single disease was actually contributing to the continuing malfunctioning of the Nigerian primary health system. Besides the lack of infrastructure, the top-down health system does not allow scope for societal choices upon the targeted diseases and the manners in which programs are carried.

Systemic problems of delivery were also responsible for the failure in polio vaccination in Nigeria. It was necessary four doses of the vaccine in order to create immunity. The government did not have an efficient bookkeeping system and did not know exactly who was already vaccinated. This was intensified by the fact that the vaccine is administrated orally and, consequently, does not leave any mark on the patient (Renne, 2006).

The shortage of human skills was another challenge faced while struggling to immunize Nigerians against polio. It was hard to find (and to train) health teams both in terms of comprehension about all distinct cultures residing within Nigerian boarders, and willingness to take these differences into consideration while delivering the vaccines. Some of them, for example, refused to wear veil in Islamic communities and did not address properly parental concerns. Others were simply not well trained and did not know how to answer questions raised by parents. There were also employees of the campaign who did not trust in the immunization program and were there only attending to their job demands (Renne, 2006).

\section{Measles, Mumps and Rubella (MMR) in the UK}

The combined shot for measles, mumps and rubella has been well succeeded around the world, except in the United Kingdom, where it has been at the core of a 
tremendous controversy. This controversy has taken place since the late 1990s (Petts \& Niemeyer, 2004), following a widely publicized report by Wakefield et al (1998) linking the vaccine to autism and Crohn's disease (Cassiday et al, 2006).

The social mobilization generated by a single article - which described only twelve cases signalizing the possibility of adverse effects - gained wide repercussion through an extensive coverage by the British media, especially after Wakefield's declaration in a press conference that there was a need for splitting the vaccine into its component parts: 1 for each disease (Horton, 2004). These scientific evidences raised by the report were not supported by epidemiological studies, neither by public health initiatives in the UK. However, MMR uptake since then fell abruptly, especially for the first dose at 13 months (Cassel et al, 2006).

This controversy has raised diverse (sometimes polarized) perceptions about MMR's usage. For example, Harris, an advocator of the vaccine, labelled dissent as 'outrageous', while, on the other hand, Stephen Glover, a Daily Mail columnist, labelled compliers as 'assassins' (Horton, 2004). There were several reasons for the decline in MMR immunization that became clear after intensive investigations on parent's attitudes towards child healthcare, as well as discussions on the roles played by the media, the government and by science in this controversy (Cassiday et al, 2006).

An important cause of dissatisfaction among the non-compliers is the fact that, despite evidences alerted by Wakefield of side effects caused by the hazardous interaction between the 3 viruses in a single shot, the National Health Service did not supply separate vaccines (one for each disease). This policy decision was justified by the higher costs of providing different shots for each disease. Parents felt that the government was risking their children's lives while prioritizing cost-effectiveness instead of dealing with scientific uncertainties (Hargreves et at, 2002).

Accordingly, people tend to trust more in independent analysts than in official statements (Burgess et al, 2006). Despite the fact that public researches receive more funding (being able to test hypothesis for bigger samples), society tends to see research sponsored by the government as biased by interest parties (Horton, 2004). This understanding has also gained strength with suspicions about the influence of pharmaceutical companies over official governmental statements (Cassel et al, 2006). Therefore, while the study of Wakerfield et al (1998) seemed neutral, the government was seen as an institution willing to find the cheapest solution possible, with the population distrusting its role in regulating risks (Cassiday et al, 2006).

It is important to observe that the longstanding downturn in MMR immunization rates is not associated with economic deprivation. Refusal to vaccinate children is rather widespread among parents of all social classes and ages (Cassiday et al, 2006). Interestingly, in some studies (e.g: Cassel et al, 2006), the non-vaccinators were in average better educated than compliers. This reinforces the hypothesis that MMR refusal is not due to lack of information or ignorance. Instead, it reflects a wider distrust 
of the government, recognition of scientific uncertainties, as well as parental anxieties toward their children healthcare.

Indeed, parental understandings of child health are much more complex than how it is conceived by British institutions. There are several social and cultural influences on health beliefs associated with low MMR uptake. Both compliers and non-compliers were supportive to immunization, and both were highly concerned about the safety of the vaccine (Cassiday et al, 2006). There is also a sense of parental responsibility in assuming personal blame for any harm to their children (Cassel et al, 2006). As reported by Fitzpatrick (2004), mothers of autistic children were wracked with guilt of having had vaccinated them for MMR and, possibly, being responsible for their disorder.

There is also a high prevalence of vegetarianism, as well as concerns about the governmental behaviour in past incidents, such as the BSE (mad cow disease) and the GMOs (genetically modified organisms) controversies, suggesting that non-compliers might be taking a precautionary approach towards scientific uncertainty. There are signals that parents may be delaying MMR vaccination until their risks are better elucidated or better options come up (Cassel et al, 2006).

Furthermore, while studies advocating for vaccination indicated misbehaviour of the British press - suggesting that they were only emphasizing the viewpoints raised by Wakefield et al (1998) - Cassiday et al (2006) demonstrated that adverse media coverage had little impact on parental attitudes to MMR. Media channels were identified as important sources of information, but there is no evidence suggesting that parents passively agreed with the messages. There was, on the other hand, an important role played by social networks in reinforcing health beliefs. Accordingly, the impact with personal face-to-face engagement with health professionals is considerably high (Petts \& Niemeyer, 2004).

Several studies also confirmed the influential role played in the refusal context, by homeopathy and lay concepts of immunity - that suggested a possible overload of viruses for a child, jeopardizing their health. According to the work published by Cassel et al (2006), 86\% of non-compliant mothers strongly agreed that 'the MMR is too much in one go'. These mothers appear to be well informed, with high interest in health-related issues, as well as concerned about food related choices.

Again, traditional theories on health would advocate for empowerment of marginalized and ignorant people while, in the case of MMR, awareness is associated to reduced acceptance. This suggests the importance of health programs to engage with concepts and beliefs that western science rejects. Informing a public that have a well-grounded dissonant scientific view is unpractical and raises ethical questions about dealing with consent in a plural society (Cassel et al, 2006).

\section{Analysis and Final Discussion}

Global health initiatives have recognized immunization as the most affordable and effective means of reducing child mortality and contribute to poverty alleviation. 
Vaccination campaigns are often designed by global organizations to be replicated among different settings, though the journey from global planning to local reality can be vulnerable and unpredictable (Yahya, 2007). Criticising global health initiatives by indicating failures in diffusing "silver bullet" technologies here is not a "Luddite" refusal of technological advancements. The cases described in the previous section were costly in economic and human terms, but are particularly insightful to understand the complexities circumscribing technological diffusion, opening up discussions on the importance of dialogue and inclusiveness for public health campaigns.

The first lesson here answers to the research question. Both cases have shown severe failures in diffusing vaccines as they neglected social, political and cultural dimensions. Technological diffusion, especially one that targets such a sensitive issue (child health), is far from being straightforward. Several characteristics around vaccination refusal, nonetheless, are often masked as ignorance, lack of information or misunderstanding. For instance, the governmental positioning in the UK towards the MMR failure has been of blaming dissent scientific perspectives and the role of media in spreading 'the untruth', while the failure in Nigeria was seen exclusively as a matter of political instability and religious conflicts.

Rather than delegitimizing vaccination refusal, the previous section has shown that reasons for vaccination failures in the UK and Nigeria go much beyond how they have been casted. Parental anxieties need to be taken comprehensively, as they are embedded by past experiences regarding science and the government behaviour, and also with what is essentially normative: what is desired for healthcare (Fairhead \& Leach, 2007).

In fact, there are several similarities across MMR and Polio refusal - even in settings that are so culturally, socially, politically and economically different. Observing the complexity of the cases and evidencing their similarities have great implications to governance mechanisms in diffusing medical technologies. These similarities are summarized in the table below.

Table 1- Similarities across Cases

\begin{tabular}{|l|l|}
\hline Criteria & Polio in Nigeria+ MMR in the UK \\
\hline C1 & Drug centred approach to immunize children \\
\hline C2 & Administrative, top-down governance \\
\hline C3 & Bureaucratic decision making \\
\hline C4 & No scope for societal choices on what should be prioritized for health care \\
\hline C5 & Societal mistrust on governmental behaviour \\
\hline C6 & $\begin{array}{l}\text { Prevalence of medical knowledge, without integrating interdisciplinary theories and lay } \\
\text { understandings on healthcare }\end{array}$ \\
\hline C7 & Expert opinion and administrative decisions were paramount \\
\hline
\end{tabular}


These similarities suggest a clash between global objectives and societal priorities and understandings on healthcare. Though sometimes it is more costly than just making medicines available, commitments to people-centred approaches are more promising, turning disease-specific vaccination campaigns into broader healthcare programs. This observation confirms the hypothesis that healthcare initiatives tend to be focused in diffusing technologies.

A challenge of technological diffusion is responding to different needs and vulnerabilities. Single approaches for mass immunization are nonetheless backed by particular scientific viewpoints and, consequently, intertwined with institutional and power relations (Jasanoff, 2005). Addressing health cannot be dissociated from people's priorities, understandings, and, therefore, it is essential to promote inclusiveness and interdisciplinarity in its governance. The table below summarizes the main differences between bottom-up and top-down healthcare approaches.

Table 2 - Top-Down vs. Bottom-Up HealthCare Approaches

\begin{tabular}{|l|l|l|}
\hline Criteria & Top-Down Global Health Campaigns & Bottom-up Health Care \\
\hline C1 - Context & One size fits all & $\begin{array}{l}\text { Recognizes the importance of contex- } \\
\text { t-specific solutions }\end{array}$ \\
\hline C2 - What & Drug-centred approach & $\begin{array}{l}\text { Patient-centred approaches, with } \\
\text { treatments based on social anxieties } \\
\text { and needs }\end{array}$ \\
\hline C3 - Why & Ease of implementation \& scaling-up & More inclusive to local specificities \\
\hline Drug development and undifferentiated & $\begin{array}{l}\text { Combines social engagement, interdis- } \\
\text { ciplinary knowledge, and diffusion of } \\
\text { medical technologies }\end{array}$ \\
\hline
\end{tabular}

Source: elaborated by the author

Accordingly, virtually no provisions exist to allow the "world's poor to say what they want, decide which projects serve their needs, or adopt local innovations" (Garett, 2007:16). There is a lack of systemic approaches matching societal needs with financial resources that are available. Policy approaches that are dismissive of the conceptual worlds of individuals and insensitive to connect clinic attendance, health trajectories and social relations, are not keen on succeeding in diffusing vaccines. This might be increasingly important, as global political tensions and scientific and technologic uncertainties will likely intensify in future (Fairhead \& Leach, 2007).

Indeed, several contemporary controversies regarding vaccination programs have been evidenced in different contexts in the last years. That is the recent case of the "no jab no play" controversy in Australia ${ }^{6}$ and the killing of healthcare officials in Pakistan ${ }^{7}$. The recurrence of vaccination refusal and the mishandling of governments towards non-compliance demonstrate the necessity of increasingly take into account bottom- 
up approaches, which would integrate people's anxieties, beliefs and priorities with interdisciplinary bodies of knowledge.

People, in general, want functioning health system addressing the wider range of diseases they prioritise, and want to be confident that healthcare teams share their interests. It is essential to shift towards pluralistic approaches that are not overwhelmingly reliant on 'experts', but rather patient-centred, integrating scientific knowledge with what is desired by the public (Fairhead and Leach, 2007). In other words, instead of getting trapped into an unproductive 'expert vs public' debate, the challenge is to embrace the different forms of expertise offered, to view these as a resources rather than burdens.

A relevant issue here regards appreciating complementarities between traditional healthcare and alternative therapies - e.g: indigenous healing knowledge, homeopathy, and food related concerns. These alternatives are not opposite to allopathic medicine and complementarities can be seen as opportunities for creating solid and better accepted healthcare systems (Fairhead and Leach, 2007).
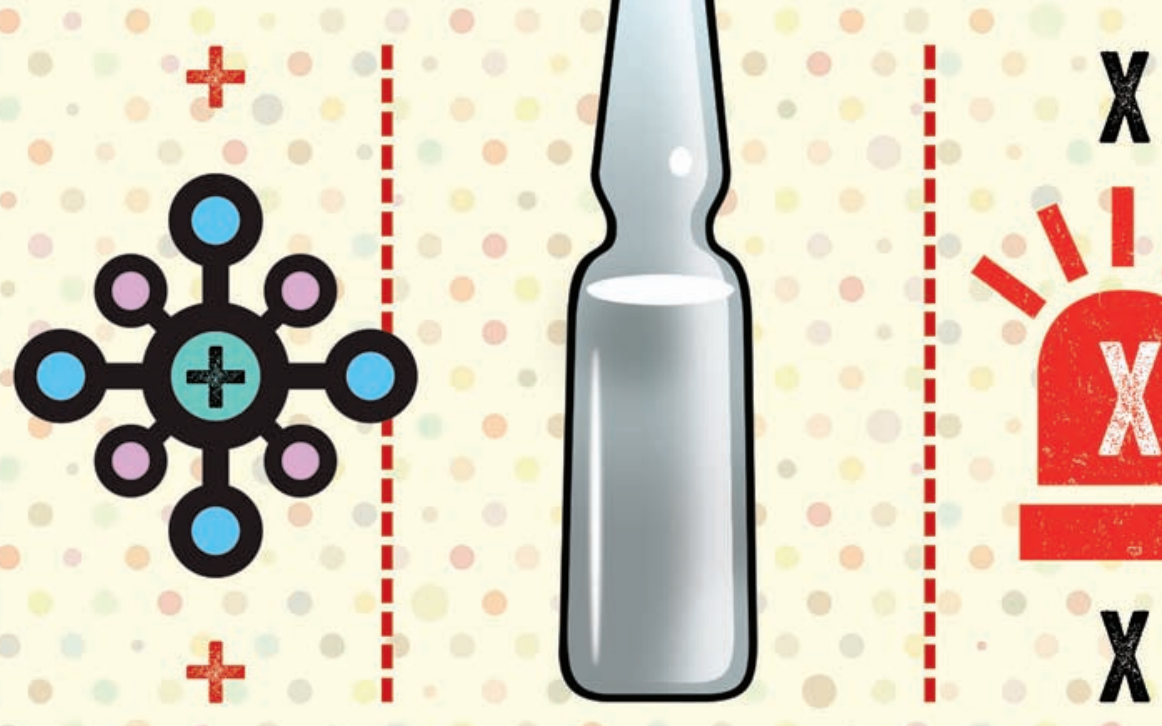

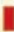
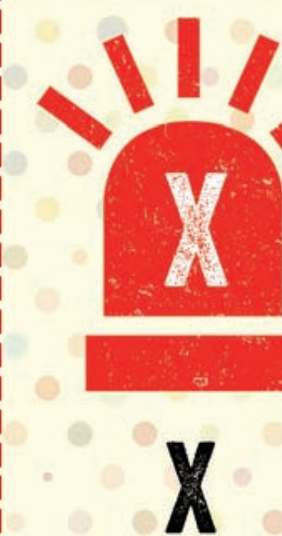
Mobilizations, such as the refusal to Polio and MMR, are also consonant with arguments in favour of democratization of science and technology. If these are to meet public needs, policies should foster democratic decisions on the directions healthcare should pursue, opening-up appraisal to different values, interests and desires. The similarities observed between the two cases of failures in diffusing "silver bullet" technologies are evidences of the importance of deliberately evaluative approaches to technological governance (Stirling, 2007). As shown by the cases, inclusive and bottom-up governance settings are not only a matter of public desirability, but rather of analytical rigor, as the diffusion of technologies are keener on failing when driven by top-down processes. Social engagement throughout healthcare processes can also stimulate local innovativeness and learning, as new'solutions' based on their own capabilities might arise.

It is important, though, to stress that this work was limited to two case studies, capable of contributing with insightful experiences to address the research question. Although examples arose in different settings, they share similarities that provide important implications for governance of healthcare systems as well as of science and technology. This work also confirmed a hypothesis that directions pursued by major health initiatives are lacking efficacy. The imperative for democratization of health related choices is not only a matter of desirability, but also of analytical rigor, as topdown, drug-centred approaches are keener on failing.

Ways forward in deepening scientific knowledge about this topic could use different regions, so to test their differences towards health programs. Moreover, other healthcare failures could be overlapped with the two cases presented in this work, so to check if they also share same similarities and, consequently, increase analytical robustness. Future quantitative research on that topic would also contribute to understand the connections between variables in a wider sample.

\author{
Notas \\ ' Such as the push-pull controversy in linear models of innovation \\ ${ }^{2}$ Cited by Stirling, 2007:289 \\ ${ }^{3}$ From: http://www.news24.com/Africa/Features/Naccine-boycott-spreads-polio-20040211 \\ ${ }^{4}$ From: http//:www. IrinNews.org \\ ${ }^{5}$ From: www.ReliefWeb.com \\ ${ }^{6}$ http://www.abc.net.au/unleashed/4706004.html \\ ${ }^{7}$ http://www.theguardian.com/world/2013/jun/16/pakistan-militants-kill-health-workers
}

\title{
Referências bibliográficas
}

ACERO, L; SAVAGET, P (2011). As pesquisas e terapias com células-tronco no Brasil: as perspectivas de diferentes grupos sociais sobre o progresso cientifico e técnico e os conhecimentos especializados e leigos. Revista Brasileira de Ciência, Tecnologia e Sociedade, v.2, n.2, p.100-129.

ACHEBE, C. (2004). The polio epidemic in Nigeria: A public health emergency (14 July). Available at: http://www.nigeriavillagesquare1.com/ Articles/CCAchebe4.htm 
ALBUQUERQUE, E (1997). Notas sobre os determinantes tecnológicos do catching-up: uma introdução à discussão sobre o papel dos sistemas nacionais de inovação na periferia. Estudos econômicos, São Paulo, v. 27, n. 2, p. 221-253, mai/ago, 1997.

ARTHUR, W (1988). Competing technologies. In: Dosi, G., Freeman, C., Nelson, R., Silverberg, G., Soete, L._Eds..,Technical Change and Economic Theory. Pinter, London, pp. 590-607.

BERKHOUT, F; MACKERRON, G (2009). Learning to listen: institutional change and legitimation in UK radioactive waste policy, Journal of Risk Research 12 (7\&8) pp. 989-1008.

BLUME, S (2006). Anti-vaccination movements and their interpretations. Social Science \& Medicine vol.62, p.628-642.

BURGESS, D., BURGESS, M., LEASK, M (2006). The MMR vaccination and autism controversy in United Kingdom 1998-2005: Inevitable community outrage or a failure of risk communication? Vaccine, vol.24, p.3921-3928.

CASTRO, A. C (2004).Construindo Pontes: Inovações, Organizações e Estratégias como Abordagens Complementares. Revista Brasileira de Inovação, Rio de Janeiro, v. 3, n.2 Agos/Dez, p. 449-473.

CASSELL, J. A., LEACH, M., POLTORAK, M. S., MERCER, C. H., IVERSEN, A. \&FAIRHEAD, J. R. (2006). Is the cultural context of MMR rejection a key to an effective public health discourse? Public Health 120(9): 783-794.

CASIDAY R, CRESSWELL T, WILSON D, PANTER-BRICK C. A survey of UK parental attitudes to the MMR vaccine and trust in medical authority. Vaccine, vol.24, p.177-84.

CASSIOLATTO, J; LASTRES, H (2005). Sistema de inovação e desenvolvimento as implicações de política, São Paulo Perspectivas, vol.19 no.1 Jan./Mar, 2005.

CHESBROUGH, H (2006). Open Innovation: the New Imperative for Creating and Profiting from Technology. Harvard Business School Press.

CHRISTENSEN, C (2000). The innovator's dilemma. New York: Harper Business.

CORIAT, B. AND WEISTEIN, O (2002). Organizations, Firms and Institutions in the Generation of Innovation. Research Policy 31, pp. 273-290.

COWAN, R; DAVID, P; FORAY, D (2000). The Explicit economics of Knowledge Codification and Tacitness, Industrial and Corporate Change, Vol. 9, No. 2, pp. 211-253.

DOSI, G; NELSON, R; WINTER, S (1999). Introduction, in Dosi, G., R. R. Nelson \& S. G. Winter (Eds.), The Nature and Dynamics of Organizational Capabilities.Forthcoming, Oxford University Press, Oxford.

EIGEN, M (1997). O que restará da biologia do século XX? In Murphy \& O'Neil (org). O que é vida? 50 anos depois: especulações sobre o futuro da Biologia. São Paulo: Unesp, 33.

EISENHARDT, K. M., \& GRAEBNER, M. E. (2007). Theory Building From Cases: Opportunities and Challenges. Academy of Management Journal, 50(1), 8.

ELBE, S (2005). AIDS, Security, Biopolitics. International Relations, SAGE Publications.

England (2007) Are we spending too much on HIV? BMJ, vol.334, p.334-344.

FEILDENBATTERSBY ANALYSTS (2005), The state of routine immunization services in Nigeria and reasons for current problems. Bath, UK: FBA Health Systems Analysts.

Fitzpatrick, M., 2004, MMR and Autism: What parents need to know. London: Routledge.

FREEMAN, C (1979). The determinants of innovation.Futures, June, 206-215, 1979.

FREEMAN, C (1987). Technology Policy and Economic Performance: Lessons from Japan, London, Frances Pinter. 
FREEMAN, C; LOUCA, F (2001). As Time Goes By: From the Industrial Revolution to the Information Revolution. Oxford University Press: Oxford.

FREEMAN, C; PEREZ, C (1998). Structural Crises of Adjustment, Business Cycles and Investment Behavior., in Dosiet al (eds) Technical change and economic theory. London: Pinter, 1988.

FREEMAN, C; SOETE, L (2000). The economics of industrial innovation. Cambridge: The MIT Press.

FREEMAN, R; REED, D (1984). Stockholders and Stakeholders: A new perspective on Corporate Governance. 3 ed. [S.I.]: California Management Review, Spring83, pp. 88-106. vol. 25.

Garrett, L (2007). The challenge of global health. Foreign Affairs, 86: 14-38.

HARGREAVES, I., LEWIS, J. \& SPEARS, T. (2002).Towards a better map: Science, the public and the media. Swindon: ESRC.

HODGSON, G (2005). 'Institutions and Economic Development: Constraining, Enabling and Reconstituting', in Dymski, G. and De Paula, S, Reimagining Growth: Towards a Renewal of Development Theory, (London and New York: Zed Books), pp.88-95.

HORTON R (2004). The lessons of MMR. Lancet; 363:747-9.

JASANOFF, S (2005).Designs on nature: science and democracy in England and the United States. Princenton: Princeton University Press.

JASANOFF, S (2009). Governing innovation. Paper presented at Knowledge in Question: a symposium on interrogating knowledge and questioning science, May 2009.

KLINE, S; ROSENBERG, N (1986). An Overview of Innovation, in Landau, R; Rosenberg, N.(orgs.), The Positive Sum Strategy, Washington, DC: National Academy of Press, 1986.

FAIRHEAD, JAMES AND LEACH, MELISSA (2007) Vaccine Anxieties: Global Science, Child Health and Society. Science in Society, Taylor \& Francis, London.

LEYDESDORFF, L (2000). The triple helix: an evolutionary model of innovations. Research Policy, $29,243-255$.

LUNDVALL, B (1988). Innovation as an Interactive Process: From User-Producer Interaction to the National System of Innovation. In: Dosi, G et al(Ed.).Technical Change and Economic Theory. Londres: Pinter Publishers, p. 349-369.

LUNDVALL, B (1992) National systems of innovation: towards a theory of innovation and interactive learning. London: Pinter.

MALERBA, F (2004). Sectoral systems of innovation: basic concepts. In: Sectoral System of Innovation: Concepts, Issues and Analysis of Six Major Sectors in Europe, Malerba, F (Ed.). Cambridge University Press, Cambridge, pp. 9-41.

MILLSTONE, E (2007). Can food safety policy-making be both scientifically and democratically legitimated? If so how? Journal of Agricultural and Environmental Ethics, vol. 20, pp 483-508.

NELSON, R., SAMPAT, B (2001). Making Sense of Institutions as a Factor Shaping Economic Performance.Journal of Economic Behavior and Organization, 44, 31-54.

NELSON, R; WINTER, S (1982). An evolutionary theory of economic change. Cambridge, MA: Belknap Press.

PETTS J, NIEMEYER S (2004). Health risk communication and amplification: learning from the MMR vaccination controversy. Health Risk Soc, 6:7-23.

PORTER, M (1990). The competitive advantage of Nations. New York: Mcmillan.

RENNE, (2006). Perspectives on polio and immunization in Northern Nigeria. SocSci Med. 63(7):1857-69. 
SCHUMPETER, J (1984). Capitalismo, socialismo e democracia: destruição criadora. Rio de Janeiro: Zahar.

SCHUMPETER, J. A (1982).Teoria do desenvolvimento econômico. São Paulo: Abril Cultural, 1982.

Solow, R (1956). A Contribution to the Theory of Economic Growth. Quarterly Journal of Economics, 70 (1): 65-94.

STIRLING, A (2007). Deliberate futures: Precaution and progress in social choice of sustainable technology. Sustainable Development 15:286-95.

TAVERNE, D. 2005. The march of unreason: Science, democracy and the new fundamentalism. Oxford, UK: Oxford University Press.

TEECE, D (1988). The Dynamic Capabilities of Firms: an Introduction, in Dosi, G; Teece, D., and Chytry, J - Technology, Organization, and Competitiveness: Perspectives on Industrial and Corporate Change, Oxford University Press, pgs. 193 a 214.

TIDD, J (2001). Innovation management in context: environment, organization and performance. International Journal of Management Review, 3(3), 169-83.

VAN DE VEN, A (1986). Central problems in management of innovation. Management Science, Vol 32, No 5.

VIOTTI, E (2002). National Learning Systems: A new approach on technological change in late industrializing economies and evidences from the cases of Brazil and South Korea, Technological Forecasting and Social Change, Vol 69, pp. 653-680.

VON HIPPEL, E (2001). Perspective: User toolkits for innovation. Journal of Product Innovation Management, 18(4), 247-257, 2001.

WAKEFIELD A, MURCH S, ANTHONY A, LINNELL J, CASSON D, MALIK M, et al (1998). lleallymphoid-nodular hyperplasia, non-specific colitis, and pervasive developmental disorder in children. Lancet; 351:637-41.

WHO (2003). Global Polio Eradication Initiative Progress 2002.Polio 03/02, Geneva, Switzerland.

YAHYA, M (2007). Polio vaccines: 'No thank you!' Barriers to polio eradication in Northern Nigeria, African Affairs 106/423 (2007), pp. 185-204.

YIN, R (2009). Case Study Research: Design and Methods. Fourth Edition. SAGE Publications. California, 2009.

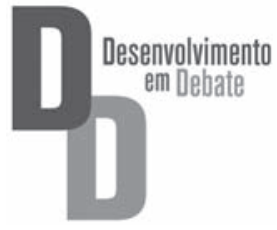

